François Catzeflis*, Gérard Issartel and Julien Jemin

\title{
New data on the bats (Chiroptera) of Martinique island (Lesser Antilles), with an emphasis on sexual dimorphism and sex ratios
}

https://doi.org/10.1515/mammalia-2018-0121

Received July 10, 2018; accepted October 30, 2018

\begin{abstract}
For deciphering the biodiversity of native mammals on the island of Martinique (Lesser Antilles), bats (Chiroptera) were netted in various localities during the course of two separate studies spanning 2004-2015. A total of 2613 individuals were caught in ground-level mist nets at 79 localities. In this study, we concentrate on 1859 captures of nine species of bats caught at 24 capturerich localities. We provide sex-ratio values, forearm and body weight measurements for each taxon. The order of decreasing abundance in captures was Artibeus jamaicensis, Sturnira angeli, Brachyphylla cavernarum, Monophyllus plethodon, Myotis martiniquensis, Molossus molossus, Ardops nichollsi, Pteronotus davyi and Tadarida brasiliensis. Our results suggest a strong sex-bias in capture rates, with males much more abundant for Ardops and Monophyllus, whereas females are more abundant for Molossus, Pteronotus and Sturnira. A clear sexual dimorphism exists with larger females in Ardops and Pteronotus, whereas males are larger in Molossus, Monophyllus and Sturnira. Reproductive females (pregnant, lactating) were found almost exclusively during the dry season (January to June) for A. jamaicensis, M. plethodon and S. angeli.
\end{abstract}

Keywords: Chiroptera; reproduction; sex ratio; sexual size dimorphism; West Indies.

\section{Introduction}

The relationship between secondary sexual dimorphism and unequal sex ratios is critical to a few evolutionary

*Corresponding author: François Catzeflis, Faculté des Sciences, ISEM, Université de Montpellier, CNRS, IRD, UMR-5554 CNRS, 34095 Montpellier, France, e-mail: Francois.catzeflis@umontpellier.fr Gérard Issartel: Société Française pour l'Etude et la Protection des Mammifères, Charbouniol, 07210 Rochessauve, France Julien Jemin: Groupe Mammalogique et Herpetologique du Limousin, Chez Pouyaud, 87240 Saint-Sylvestre, France; and Société Française pour l'Etude et la Protection des Mammifères, 18000 Bourges, France theories (Emlen and Oring 1977, Daly and Wilson 1978). In bats, both male-biased and female-biased size dimorphism have been documented (Myers 1978, Willig and Hollander 1995), although the underlying causes of sexlimited selection pressures have not been demonstrated for any species.

Similarly, the direction and magnitude of sex ratio deviating from parity is most often related to polygamous mating systems. When the number of adult females outnumbers that of adult males, harems have been suspected (e.g. Artibeus jamaicensis Leach, 1821: McCracken and Wilkinson 2000). Quite a few species of bats have a strong excess of males, and the mating system in such species has sometimes been called a "mating swarm" (e.g. Neotropical Emballonuridae: Bradbury and Vehrencamp 1977).

In most species of bats where sexual dimorphism is documented, females are larger than males. Myers (1978) suggested that female-biased size dimorphism in vespertilionid bats reflects an adaptive response to the aerodynamic challenges of flight during pregnancy, lactation or the transport of suckling young. According to this hypothesis, larger females is an allometric effect of selection for reduced wingloading. By contrast, Williams and Findley (1979) argued that increased female size in vespertilionid bats reflects an adaptive response to the metabolic demands of maintaining thermal homeostasis during pregnancy.

Despite the fact that most islands from the West Indies have been surveyed for their populations of bats (reviews in Willig et al. 2010 and in Pedersen et al. 2013), the island of Martinique has not yet benefitted from large efforts aimed at characterizing its chiropteran fauna.

Martinique is a French overseas department, with an area of ca. $1100 \mathrm{~km}^{2}$. It is located near the center of the Lesser Antillean chain, between $14^{\circ} 23^{\prime}$ and $14^{\circ} 52^{\prime}$ north latitude and between $60^{\circ} 48^{\prime}$ and $61^{\circ} 13^{\prime}$ west longitude. Martinique is one of the Windward Islands in the southern Lesser Antilles, ca. $40 \mathrm{~km}$ south of Dominica and $30 \mathrm{~km}$ north of St Lucia. The north of the island is very mountainous, dominated by the Pitons du Carbet (1207 m) and Montagne Pelée (1397 m), an active (and closely monitored) volcano. Across the rest of the island, the relief primarily comprises hills (called "mornes"), the tallest of which reaches $505 \mathrm{~m}$ (Montagne du Vauclin) and $478 \mathrm{~m}$ (Morne Larcher) in the 
municipality of Diamant. There is just one flat area - the plain of Le Lamentin in west-central Martinique - amongst the hills (Teissier du Cros and Vidal 2006).

Martinique has a dry season from January to May and a hurricane season from July to September (Albert and Spieser 1999). As in other islands of the Lesser Antilles, the climate may vary considerably over a short distance. For example, annual precipitation is about $950 \mathrm{~mm}$ at the south-east coast, whereas it reaches $5500 \mathrm{~mm}$ in the mountainous forests of the north of Martinique. With these differences in rainfall and topography, a wide diversity of habitats cover the island, ranging from xerophytic shrublands and dry forest, to wet tropical forest, high altitude grasslands and savannas and mangroves.

Some $30 \mathrm{~km}$ to the south, the smaller $\left(603 \mathrm{~km}^{2}\right)$ island of Saint Lucia has nine species of bats (the same taxa as found on Martinique; Scott Pedersen personal communication, March 2017); and $40 \mathrm{~km}$ to the north, the slightly smaller $\left(790 \mathrm{~km}^{2}\right)$ island of Dominica has 12 species of bats (the same as in Martinique, plus the vespertilionid Eptesicus fuscus (Beauvois, 1796): Genoways et al. 2001).

As for almost all Windward Islands, the habitat and local climate on Martinique have been altered significantly as a result of early settlement by Europeans beginning in the 1500s. Changes due to agricultural practices have destroyed much of the original environment, but fortunately there still exist large tracts of mid elevation (mostly between 300 and $800 \mathrm{~m}$ ) wet tropical forests covering approximately $90 \mathrm{~km}^{2}$ (Joseph 2016).

The island of Martinique is home to 11 species of bats from six families (Baker and Genoways 1978, Willig et al. 2010, Pedersen et al. 2013). Here, we provide data on abundance, elevational distribution, morphometry and reproduction for nine species: Ardops nichollsi (Thomas, 1891), Artibeus jamaicensis Leach, 1821, Brachyphylla cavernarum Gray, 1834, Monophyllus plethodon Miller, 1900, and Sturnira angeli de la Torre, 1966 (Phyllostomidae), Pteronotus davyi Gray, 1838 (Mormoopidae), Molossus molossus (Pallas, 1766) and Tadarida brasiliensis (I. Geoffroy, 1832) (Molossidae) and Myotis martiniquensis (LaVal, 1973) (Vespertilionidae).

Most of the data were gathered during the course of two separate, independent projects: a biodiversity inventory aimed at linking bat communities and forest types (Barataud et al. 2015) and an ecological study of the frugivorous bats feeding in orchards of guavas (Psidium guajava Linné, 1753) (Picard and Catzeflis 2013). The biodiversity survey used bioacoustic recordings as well as mist netting in forested areas, whereas the ecological study used mist netting in agricultural landscapes with plantations of fruit trees.

\section{Materials and methods}

\section{Sampling}

Bats were sampled during several field trips between March 2004 and December 2015. Capture methods included mist netting for bats in various localities across most of the island, from sea level up to an elevation of $780 \mathrm{~m}$. Netting locations were selected based on two criteria: (a) for covering most types of natural forests: mangroves, beach forests, dry forests, semi-moist forests and rainforests (see Teissier du Cros and Vidal 2006 for more information on Martinique forests); and (b) in various agricultural plantations where orchards of guavas had been known for being visited by bats consuming fruits.

Mist nets (mesh size $=16 \mathrm{~mm}$ ) of height $2.6 \mathrm{~m}$ and of lengths varying from 3 to $10 \mathrm{~m}$ were employed at the ground level. Sampling effort was quantified as the product of mist net length (in meters) by the duration (in hours) the nets were in use for a particular locality. External measurements [forearm length (FA) measured with dial calipers to the nearest $0.1 \mathrm{~mm}$; body mass - weight (W) - to the nearest $0.5 \mathrm{~g}$ ] were recorded on all bats before they were released. Gender and reproductive status were ascertained from external characteristics (e.g. enlarged nipples or testes) (Racey 2009).

As bats are protected by law in Martinique, all sampling and handling of these animals were done in accordance with state permits issued by Prefecture de Martinique.

We follow the molecular revision by Velazco and Patterson (2013) for naming the Little yellow-shouldered bats of Martinique Sturnira angeli de la Torre 1966, whereas the previously used name Sturnira lilium (E. Geoffroy 1810) is restricted to Paraguay and south-east Brazil.

A selection of 31 specimens (Appendix 1) were kept and euthanized following the guidelines of the American Society of Mammalogists for the use of wild mammals in research (Sikes and Gannon 2011). These specimens were preserved as scientific vouchers at Montpellier University and/or Paris Museum National d'Histoire Naturelle (MNHN) for further morphological and genetic analyses.

Correlation tests (Pearson's R; Kendall's tau) and univariate statistical tests for comparing measurements between groups included chi-square tests (with unequal variance: $\chi^{2}$ ) and Mann-Whitney nonparametric tests (MW), as implemented by the software PAleontological STatistics (PAST: Hammer et al. 2011).

We caught bats from March 2004 to December 2015 at 79 localities spanning all 34 administrative units ("communes") of the island. Sample sizes ranged from two to 
261 individuals per locality, and we focused on the 26 locations where at least 30 bats were caught (Table 1). Most (21 out of 26) capture-rich sites were resampled at 2-5 different times at dates separated by at least 6 months, but each sampling date was during only one evening.

To test if the samplings were dependent upon the climate, we compared a dry season to a wet season. Based on Meteo France (see Albert and Spieser 1999), the average monthly precipitation spanning 30 years (1971-2000) indicates that the six driest months are from January to June (average $111 \mathrm{~mm}$, standard deviation $24 \mathrm{~mm}$, range: 89-153 mm) whereas the six wettest months are from July to December (average $230 \mathrm{~mm}$, standard deviation 47, range: $160-267 \mathrm{~mm}$ ) (values at http://www.meteo.fr/ temps/domtom/antilles/pack-public/meteoPLUS/climat/ climat_mart.htm).

To test if relative species abundances in our samples were dependent upon the elevation, we examined the distribution of captures within five elevational zones: from sea level up to $150 \mathrm{~m}$; between 151 and $300 \mathrm{~m}$; 301 to $450 \mathrm{~m}$; 451 to $600 \mathrm{~m}$ and 601 to $750 \mathrm{~m}$.

\section{Results}

Our whole data set for Martinique bats includes 2613 individuals from nine species, caught after a mist netting effort of 17,743 m-h. By decreasing abundance, these are 902 Artibeus jamaicensis, 498 Stumira angeli, 326 Brachyphylla cavernarum, 302 Monophyllus plethodon, 218 Myotis martiniquensis, 188 Molossus molossus, 112 Ardops nichollsi, 44 Pteronotus davyi and 23 Tadarida brasiliensis.

Collecting efforts were heterogeneous in space and time, with most locations yielding few bats. Altogether bats were sampled in 79 localities, with an average of 33 captures per locality. Two roosts (sampling effort of $110 \mathrm{~m}$-h) were sampled at dusk for emerging bats: Chateau Aubery (108 Brachyphylla cavernarum) and Morne Vert (33 Molossus molossus). We caught 1350 bats (51.7\% of the total sample) during the dry season (January to June) and 1263 (48.3\% of the total sample) during the wet season (July to December).

Fewer than 30 bats were netted at the majority ( 53 out of 79) of the sampled sites. However, there were 24

Table 1: List of 26 localities (24 for catching foraging bats and two for sampling roost-emerging bats) of Martinique where at least 30 individuals have been caught.

\begin{tabular}{|c|c|c|c|c|c|}
\hline Locality & Number on map & Municipality & Sample size & Elevation & Coordinates \\
\hline Cassière & 1 & Les Anses d'Arlets & 55 & 64 & $14^{\circ} 30^{\prime} \mathrm{N} ; 61^{\circ} 04^{\prime} \mathrm{W}$ \\
\hline Beauséjour & 2 & Grand Rivière & 261 & 120 & $14^{\circ} 52^{\prime} \mathrm{N} ; 61^{\circ} 10^{\prime} \mathrm{W}$ \\
\hline Bois Duhaumont & 3 & Marigot & 39 & 120 & $14^{\circ} 47^{\prime} \mathrm{N} ; 61^{\circ} 03^{\prime} \mathrm{W}$ \\
\hline Rivière Pirogue & 4 & Le Lorrain & 30 & 113 & $14^{\circ} 47^{\prime} \mathrm{N} ; 61^{\circ} 04^{\prime} \mathrm{W}$ \\
\hline Château Aubéry (roost) & 5 & Ducos & 108 & 150 & $14^{\circ} 36^{\prime} \mathrm{N} ; 60^{\circ} 56^{\prime} \mathrm{W}$ \\
\hline Montagne du Vauclin & 6 & Le Vauclin & 55 & 280 & $14^{\circ} 33^{\prime} \mathrm{N} ; 60^{\circ} 53^{\prime} \mathrm{W}$ \\
\hline Route de Reculée & 7 & Sainte-Marie & 40 & 382 & $14^{\circ} 46^{\prime} \mathrm{N} ; 61^{\circ} 02^{\prime} \mathrm{W}$ \\
\hline Grand Macabou & 8 & Le Marin & 36 & 2 & $14^{\circ} 30^{\prime} \mathrm{N} ; 60^{\circ} 50^{\prime} \mathrm{W}$ \\
\hline Domaine d'Estripault & 9 & Le Morne Rouge & 61 & 380 & $14^{\circ} 45^{\prime} \mathrm{N} ; 61^{\circ} 06^{\prime} \mathrm{W}$ \\
\hline Bellevue (orchards) & 10 & Le Francois & 34 & 25 & $14^{\circ} 37^{\prime} \mathrm{N} ; 60^{\circ} 55^{\prime} \mathrm{W}$ \\
\hline Caplet & 11 & Le Morne Vert & 111 & 534 & $14^{\circ} 43^{\prime} \mathrm{N} ; 61^{\circ} 07^{\prime} \mathrm{W}$ \\
\hline Forêt de Montravail & 12 & Sainte-Luce & 118 & 260 & $14^{\circ} 30^{\prime} \mathrm{N} ; 60^{\circ} 56^{\prime} \mathrm{W}$ \\
\hline Forêt du Galion & 13 & La Trinité & 89 & 10 & $14^{\circ} 43^{\prime} \mathrm{N} ; 60^{\circ} 05^{\prime} \mathrm{W}$ \\
\hline Morne Tranchette & 14 & Le Morne Vert & 71 & 740 & $14^{\circ} 42^{\prime} \mathrm{N} ; 61^{\circ} 08^{\prime} \mathrm{W}$ \\
\hline Morne Vert (roost) & 15 & Le Morne Vert & 33 & 370 & $14^{\circ} 42^{\prime} \mathrm{N} ; 61^{\circ} 08^{\prime} \mathrm{W}$ \\
\hline Peter Maillet (orchards) & 16 & Saint-Esprit & 148 & 46 & $14^{\circ} 33^{\prime} \mathrm{N} ; 60^{\circ} 55^{\prime} \mathrm{W}$ \\
\hline Petite Rivière (orchards) & 17 & Le Lamentin & 30 & 41 & $14^{\circ} 39^{\prime} \mathrm{N} ; 60^{\circ} 58^{\prime} \mathrm{W}$ \\
\hline Rivière Blanche & 18 & Saint-Joseph & 55 & 300 & $14^{\circ} 43^{\prime} \mathrm{N} ; 61^{\circ} 05^{\prime} \mathrm{W}$ \\
\hline Plateau Boucher & 19 & Fonds-Saint-Denis & 159 & 665 & $14^{\circ} 43^{\prime} \mathrm{N} ; 61^{\circ} 06^{\prime} \mathrm{W}$ \\
\hline Plateau Cocoyer & 20 & Le Prêcheur & 37 & 260 & $14^{\circ} 50^{\prime} \mathrm{N} ; 61^{\circ} 12^{\prime} \mathrm{W}$ \\
\hline Plateau Concorde & 21 & Schoelcher & 39 & 592 & $14^{\circ} 41^{\prime} \mathrm{N} ; 61^{\circ} 06^{\prime} \mathrm{W}$ \\
\hline Ravin Saint-Pierre & 22 & Sainte-Luce & 33 & 10 & $14^{\circ} 29^{\prime} \mathrm{N} ; 60^{\circ} 57^{\prime} \mathrm{W}$ \\
\hline Fonds Manoël & 23 & Le Diamant & 81 & 9 & $14^{\circ} 30^{\prime} \mathrm{N} ; 60^{\circ} 59^{\prime} \mathrm{W}$ \\
\hline Trou Manuel & 24 & Le Marin & 106 & 4 & $14^{\circ} 28^{\prime} \mathrm{N} ; 60^{\circ} 53^{\prime} \mathrm{W}$ \\
\hline Rivière Coulée d'Or & 25 & Le Vauclin & 34 & 19 & $14^{\circ} 32^{\prime} \mathrm{N} ; 60^{\circ} 52^{\prime} \mathrm{W}$ \\
\hline Between Prêcheur and Grand Rivière & 26 & Grand Rivière & 137 & 249 & $14^{\circ} 51^{\prime} \mathrm{N} ; 61^{\circ} 12 \mathrm{~W}$ \\
\hline
\end{tabular}

Municipality stands for political unit (“commune”); sample size=number of bats caught and measured. Elevation is in meters. Localities are numbered 1-26 in Figure 1. Roosts are localities 5 and 15; orchards are localities 10, 16 and 17. 
netting locations where at least 30 foraging bats were captured after a sampling effort of 12,502 m-h and two other locations with more than 30 bats were roosts (Table 1, Figure 1). Hereafter, our analysis focuses on the 1859 individual bats netted in these 24 "capture-rich localities". Most (21 out of 24) locations were in forested areas (sampling effort of $8286 \mathrm{~m}$-h for 1647 bats), from sea-level mangroves up to mid-altitude rainforests; and three locations were in orchards (sampling effort of $4212 \mathrm{~m}$-h for 212 bats). These 24 localities were distributed across a range of elevations: most (13 localities and

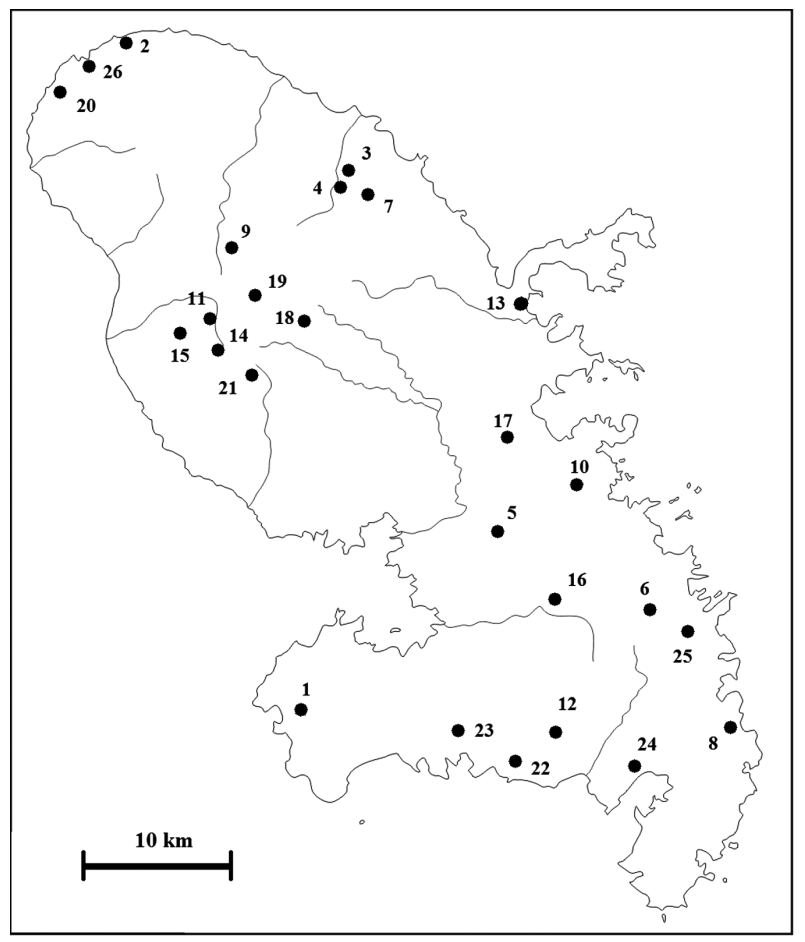

Figure 1: Map of Martinique with the 24 localities where at least 30 bats have been netted.

Added are two roosts where Brachyphylla (locality number 5) and Molossus (15) have been handled. See Table 1 for details of the localities.

Table 2: Two external measurements for Ardops nichollsi caught in various localities in Martinique.

\begin{tabular}{lll}
\hline & Forearm & Weight \\
\hline Females & $47.6 \pm 1.9$ & $22.8 \pm 2.4$ \\
& $(41.5-50.5) \mathrm{n}=23$ & $(19.0-28.5) \mathrm{n}=17$ \\
Males & $45.7 \pm 1.2$ & $20.2 \pm 1.9$ \\
& $(42.0-49.0) \mathrm{n}=89$ & $(15.5-29.0) \mathrm{n}=73$ \\
MW test & $\mathrm{p}<0.0001$ & $\mathrm{p}<0.0001$ \\
\hline
\end{tabular}

Values are presented as mean \pm standard deviation (range: minimum-maximum). $n$, sample size. $p$-Values for Mann-Whitney tests investigating sexual dimorphism.
976 captures) are between 0 and $150 \mathrm{~m}$, five sites were located at 151-300 m (402 bats) and then two sites at each subsequent level: 301-450 m (101 bats), 451-600 m (150 bats) and $601-750 \mathrm{~m}$ (230 bats).

For each taxon, we considered the whole sample (79 locations and 2613 individuals) for sex ratio, sexual dimorphism and reproductive data, and then the 24 capture-rich localities (1859 individuals) for addressing relative abundance and elevational distribution.

\section{Ardops nichollsi (Antillean tree bat)}

The whole database contains 112 Ardops nichollsi: 23 females and 89 males, and the sex ratio is strongly biased toward males $\left(\chi^{2}=21.295 ; p<0.0001\right)$. In our study, Ardops was found in many localities, but most often (12 out of 15) with a sample smaller than 10 individuals. The three localities with more than 10 animals are Montagne du Vauclin (four females and 11 males), Domaine d'Estripault (one female and 14 males), and Plateau Boucher (three females and 10 males). On Montserrat, S. Pedersen (in littera, 18 February 2010) caught slightly more males $(n=97)$ than females $(n=62)$ with a similar methodology as ours. Females are larger than males for the variables forearm (MW $\mathrm{p}<0.0001$ ) and weight (MW $\mathrm{p}<0.0001$ ) (Table 2), a sexual dimorphism already reported by Jones and Genoways (1973) for external and skull measurements in animals from Dominica island.

Four females (out of 23) were pregnant: one in February and three in March. On nearby Dominica, Genoways et al. (2001) observed four pregnant animals in March and one lactating in April. On Guadeloupe, Baker et al. (1978) recorded two lactating and six pregnant females out of 14 animals caught during the second half of July.

Among the 24 capture-rich localities, Ardops nichollsi was netted at 15 of them, for a total of 81 individuals, or $4.4 \%$ of the 1859 bats in this sample. Again, there was a strong bias in the sex ratio, with 16 females and 65 males $\left(\chi^{2}=16.32 ; \mathrm{p}<0.0001\right)$.

Ardops is less abundant at the lowest elevations (only 22\% of captures from sea level to $150 \mathrm{~m}: \chi^{2}=20.57$; $\mathrm{p}=0.0004$ ) and is commonly found up to $740 \mathrm{~m}$ at Morne Tranchette (locality 14 in Figure 1). On Guadeloupe, Baker et al. (1978) examined 52 individuals from 11 localities, ranging from elevations of 10-950 m, and their interpretation was that Ardops is a "common ... species distributed at lower elevations throughout the island". On MarieGalante (a dependency of Guadeloupe), Stoetzel et al. (2016) indicated that fossil remains of Ardops appear ca. 15,000 years ago, when aridity was at its maximum - thus 
indicating that the Antillean fruit bat can also be a loweraltitude xerophilous species.

\section{Artibeus jamaicensis (Jamaican fruit-eating bat)}

This is the most common species caught on Martinique representing 34.5\% of all 2613 bats captured; there were 418 females and 484 males, which is not different from a 1:1 sex ratio $\left(\chi^{2}=2.42 ; \mathrm{p}=0.120\right)$. Mist net captures on Montserrat included slightly more females $(n=721)$ than males $(n=574)$ (S. Pedersen, in littera, 18 February 2010). Females (excluding pregnant individuals) are as large (forearm, weight) as males in most samples (Table 3): 33 females and 11 males at Beausejour ( $M W p=0.276$ and $\mathrm{p}=0.518$ for forearm and weight, respectively); 15 females and 23 males at Forêt du Caplet (MW p =0.952 and 0.748, respectively). On Jamaica, Genoways et al. (2005) found that Artibeus jamaicensis does not exhibit secondary sexual variation in size. However, Genoways et al. (2011) found that on the island of Barbados females were larger than males for the forearm length, but this was without statistical support. Baker et al. (1978) observed that this species was the most frequently caught bat in Guadeloupe, with specimens abundant in all 11 localities surveyed by these authors.

Adult females were caught equally $\left(\chi^{2}=3.11 ; \mathrm{p}=0.211\right)$ throughout the year: 196 during the dry season and 222 during the wet season. Reproduction is mainly during the dry season: lactating females were observed in February $(n=5)$, March $(n=23)$, April $(n=2)$ and November $(n=1)$; and pregnant females were observed in February $(n=18)$ and March ( $\mathrm{n}=38)$. On Antigua, Pedersen et al. (2006) recorded reproductive females in June (one pregnant and two lactating out of six) and in July (five pregnant and 11 lactating out of 35). On Barbados, Genoways et al. (2011) noted reproductive females in May (all 11 captures were pregnant), June (15 pregnant out of 17 captures) and July (among 27 animals: 21 lactating and six pregnant).

The observed data on reproductive activity in Artibeus (the most frequent species of our database - with 902 captures) are so different between the dry (56 pregnant females out of a total of 196) and the wet (none pregnant female in reproduction out of 222) season that some interpretation can be drawn. The reproductive cycle of mainland populations of Artibeus jamaicensis has been studied extensively, and these populations have a bimodal polyestrous cycle in which a peak of parturition occurs in March and April and a second peak occurs in July and August (Wilson et al. 1991). This is also the case on nearby Dominica, where Genoways et al. (2001) also observed bimodal polyestry: a first pregnancy in January and newborns by late February and March; and a second pregnancy during April and May with births in July and August. In contrast, our data on Martinique indicate that all pregnant females were observed in February and March, and none during November and December, thus suggesting a single period of reproduction during the dry season.

Among the 24 capture-rich localities, Artibeus jamaicensis was found in 22 of them, for a total of 612 individuals, or $32.9 \%$ of the 1859 bats of this sub-sample. The sex ratio is not significantly different from 1:1, with 286 females and 326 males $\left(\chi^{2}=1.31 ; p=0.253\right)$.

Artibeus jamaicensis was more abundant - than expected by chance - at the lowest elevations (Figure 2; $72 \%$ of captures from sea level to $150 \mathrm{~m}: \chi^{2}=71.97$; $\mathrm{p}<0.0001$ ) but the species is found throughout the island, up to $665 \mathrm{~m}$ at Plateau Boucher (locality 19 in Figure 1).

On Barro Colorado island, Gardner et al. (1991) showed that there were slightly more females than males during both dry and wet seasons, with a sex ratio of 55:45. This is not the case in Martinique, where the sex ratio is not different from equilibrium during the dry (196 females and 209 males: $\left.\chi^{2}=0.2099 ; \mathrm{p}=0.6733\right)$ or during the wet season (222 females and 275 males: $\chi^{2}=2.835 ; \mathrm{p}=0.0922$ ).

Table 3: Two external measurements for Artibeus jamaicensis caught in two localities: Habitation Beauséjour in March 2007 (locality 2 on Figure 1) and Route forestière de Caplet in December 2011 (location 11 on Figure 1).

\begin{tabular}{lll}
\hline & Forearm & Weight \\
\hline Beauséjour: $\mathrm{f}$ & $60.0 \pm 2.2(55.0-65.0) \mathrm{n}=33$ & $43.0 \pm 2.6(39.0-46.0) \mathrm{n}=6$ \\
Beauséjour: $\mathrm{m}$ & $59.1 \pm 2.0(56.0-62.0) \mathrm{n}=11$ & $41.6 \pm 5.4(36.0-51.0) \mathrm{n}=8$ \\
& $\mathrm{p}=0.2765$ & $\mathrm{p}=0.5177$ \\
Caplet: $\mathrm{f}$ & $60.7 \pm 1.8(57.4-63.3) \mathrm{n}=15$ & $43.8 \pm 5.4(35.0-54.0) \mathrm{n}=15$ \\
Caplet: $\mathrm{m}$ & $60.7 \pm 2.2(57.2-65.2) \mathrm{n}=23$ & $44.3 \pm 3.9(37.0-50.0) \mathrm{n}=21$ \\
& $\mathrm{p}=0.9523$ & $\mathrm{p}=0.7481$ \\
\hline
\end{tabular}

Values are presented as mean \pm standard deviation (range: minimum-maximum). f, females; $m$, males; $n$, sample size. $p$-Values for MannWhitney tests investigating sexual dimorphism. 


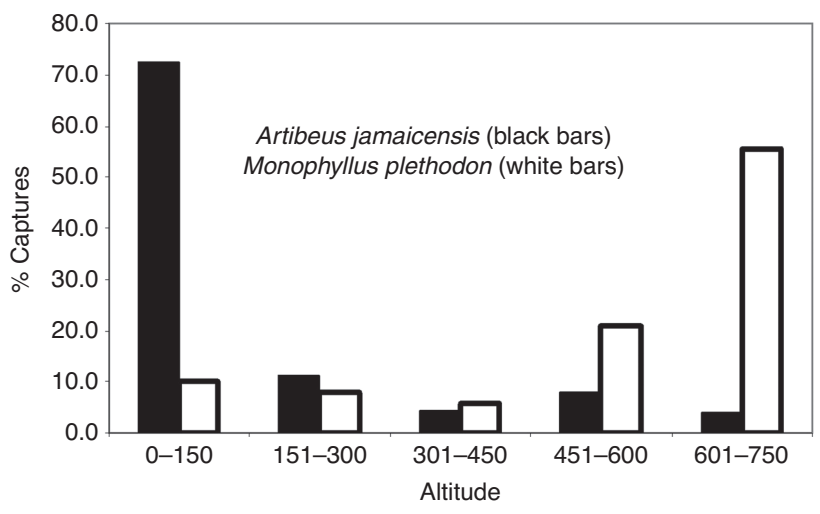

Figure 2: Relative abundances versus elevation for Artibeus jamaicensis (black bars; a total sample of 902 individuals) and Monophyllus plethodon (white bars: a total of 302 individuals). Five elevation layers were defined as indicated in the Materials and methods section.

\section{Brachyphylla cavernarum (Antillean fruit- eating bat)}

Brachyphylla cavernarum ranks third in abundance, with 326 captures or $12.5 \%$ of the total sample. With 124 males and 94 females (we here exclude the sample from the roost locality, Chateau Aubery), the sex ratio is at equilibrium $\left(\chi^{2}=2.074 ; \mathrm{p}=0.1498\right)$. On Montserrat, there appears to be slightly more females $(\mathrm{n}=182)$ than males $(\mathrm{n}=133)$, according to S. Pedersen (in littera, 18 February 2010). Females (excluding pregnant individuals) are as large (forearm, weight) as males in most samples; measurements of two samples are detailed in Table 4. Swanepoel and Genoways (1978) in their review of morphological variation throughout the Antilles found that in general males of Brachyphylla are larger than females in Martinique, but this varies from island to island: Genoways et al. (2011) found that females had a larger forearm than males on Barbados whereas on Saint Martin/Sint Maarten males were significantly larger than females (Genoways et al. 2007).

The vast majority of Brachyphylla were caught during the wet season (July to December): $74 \%$ of males and $75 \%$ of females. Pregnant females were caught in February (one individual), March (four) and December (three). On Antigua, in a large cave, Pedersen et al. (2006) recorded pregnant Brachyphylla in April (nine out of 10 females) and May (all 21 collected females) whereas in June most females had a suckling newborn. On nearby Dominica, Genoways et al. (2001) collected three pregnant females in April and four lactating females in July. On Saint Martin, Genoways et al. (2007) collected reproductive data suggesting that Brachyphylla is pregnant during March, April and May.

Brachyphylla is found in 13 among the 24 capture-rich localities, for a total of 175 individuals (or $9.4 \%$ of the total sample). Another sample of 108 individuals (69 males and 39 females) was caught when emerging from their roost in the cellars of an old building (Chateau Aubery).

On Martinique, Brachyphylla sometimes forages in large numbers in orchards of guavas (Psidium guajava), and can substantially damage the crop (Picard and Catzeflis, unpublished). Such was the case in locality 16 (an agricultural estate at the locality Peter Maillet) where we caught 24 females (none were pregnant or lactating) and 39 males with just three nets set amidst ca. 20 guava trees, on 16 November 2011. On Barbuda, Pedersen et al. (2007) also reported an important foraging activity of Brachyphylla in an orchard of mango trees (Mangifera indica): 37 captures on 04 June 2003, of which 20 were females (six lactating and eight pregnant).

Brachyphylla cavernarum is more abundant - than expected by chance - at the lowest elevations ( $87 \%$ of captures from sea level to $\left.150 \mathrm{~m}: \chi^{2}=54.99 ; \mathrm{p}<0.0001\right)$ but it is found throughout the island, up to $665 \mathrm{~m}$ at Plateau Boucher (Figure 1: locality 19).

Table 4: Two external measurements for Brachyphylla cavernarum caught at two localities: a roost at Chateau Aubéry in December 2013 (locality 5 on Figure 1) and orchards at Peter Maillet in November 2011 (number 16 on Figure 1).

\begin{tabular}{lll}
\hline & Forearm & Weight \\
\hline Aubéry: $f$ & $65.0 \pm 0.8(64.0-66.5) \mathrm{n}=8$ & $41.3 \pm 2.0(39.0-44.5) \mathrm{n}=6$ \\
Aubéry: $\mathrm{m}$ & $65.4 \pm 1.5(63.0-68.0) \mathrm{n}=17$ & $43.9 \pm 4.1(39.0-52.0) \mathrm{n}=15$ \\
& $\mathrm{p}=0.3792$ & $\mathrm{p}=0.1713$ \\
Peter Maillet: $\mathrm{f}$ & $63.9 \pm 1.7(61.0-67.0) \mathrm{n}=32$ & $41.8 \pm 4.0(36.0-48.0) \mathrm{n}=8$ \\
Peter Maillet: $\mathrm{m}$ & $64.0 \pm 1.6(61.0-67.5) \mathrm{n}=50$ & $43.8 \pm 5.5(36.5-56.0) \mathrm{n}=10$ \\
& $\mathrm{p}=0.9619$ & $\mathrm{p}=0.1429$ \\
\hline
\end{tabular}

Values are mean \pm standard deviation (range: minimum-maximum). $f$, females; $m$, males; $n$, sample size. $p$-Values for Mann-Whitney tests investigating sexual dimorphism. 


\section{Molossus molossus (Pallas' mastiff bat)}

Molossus molossus is the most commonly netted molossid with 188 captures or $7.2 \%$ of the whole data set. This may be the most abundant species of bat on the island of Martinique, but our sampling with mist nets clearly underestimates their populations because we observe many more individuals hunting above the reach of our nets (Larsen et al. 2007). As can be expected from a species whose social organization includes a harem (Gager et al. 2016), we caught more females than males (131 and 57, respectively; $\left.\chi^{2}=15.15 ; p<0.0001\right)$. During the wet season, the sex ratio appeared at equilibrium (38 females and 30 males: $\chi^{2}=0.472 ; p=0.492$ ) whereas females were much more numerous than males during the dry season (73 females and 17 males: $\left.\chi^{2}=12.29 ; \mathrm{p}<0.0001\right)$. On Montserrat, $\mathrm{S}$. Pedersen (in littera, 18 February 2010) caught many more females $(n=406)$ than males $(n=78)$.

Females are smaller than males, as exemplified for forearm and weight measures (Table 5). On Guadeloupe (Genoways et al. 1981) and Barbados (Genoways et al. 2011), males were also found to be larger than females. Most Molossus molossus were caught during the dry season ( $71 \%$ of captures between January and June). Few breeding females were encountered: four in March (three lactating, one pregnant) and one in November. On Antigua, Pedersen et al. (2006) recorded reproductive females in June (eight pregnant out of 11) and July (three pregnant and one lactating out of seven). On Barbados, Genoways et al. (2011) reported reproductive females in May (all 13 females were pregnant), June (six pregnant out of 10 captures) and July (one pregnant and 11 lactating out of 17). On Dominica, Genoways et al. (2001) found reproductive females in April (six pregnant out of 13 animals) and July (13 lactating out of 14 individuals).

Molossus was netted in only 11 of the 24 capture-rich localities - and its abundance is as low (135 captures or $7.3 \%)$ as in the whole data set. Molossus was caught from sea level up to $534 \mathrm{~m}$ (Forêt du Caplet - locality 11 in Figure 1). Another sample of 33 Pallas' mastiff bats (23 non-reproductive females and 10 males) was netted during their emergence from the roost (a tin roof of a small house) in the village of Morne Vert on 25 February 2015.

\section{Monophyllus plethodon (Antillean long- tongued bat)}

The nectarivorous Monophyllus plethodon is fairly common in Martinique - 302 individuals were caught or $11.6 \%$ of the whole data set. It was found in 12 of the 24 capture-rich localities, for a total of 259 individuals (or $13.9 \%$ of this sub-sample).

There is a strong bias in the sex ratio, with many more males than females (229 versus $73 ; \chi^{2}=43.17 ; \mathrm{p}<0.0001$ ). Two localities yielded more than 50 captures of Monophyllus: Morne Tranchette (locality 14 in Figure 1) and Plateau Boucher (locality 19) which are separated by ca $3.5 \mathrm{~km}$. Morne Tranchette had 56 males and 10 females, whereas Plateau Boucher yielded 80 males and 14 females (males are much more abundant: $\chi^{2}=32.06$ and 46.34 , respectively; $\mathrm{p}<0.0001$ in both comparisons). On Montserrat, S. Pedersen (in littera, 18 February 2010) caught more females $(n=112)$ than males $(n=86)$, but that difference is not statistically supported $\left(\chi^{2}=3.414 ; p=0.1814\right)$.

Two samples (at localities Forêt de Caplet, 13 females and 22 males, and Morne Tranchette, 10 females and 56 males) indicate that the forearm of females is smaller than in males (MW p $=0.032$ and 0.00076 , respectively) whereas both sexes have a similar weight (MW $p=0.676$ and 0.309, respectively) (Table 6). A third sample (Plateau Boucher: locality 19) has females $(n=14)$ smaller than males $(\mathrm{n}=80)$ for both the forearm and the weight measurements (MW p $=0.0126$ and 0.0045, respectively). On Barbados, Genoways et al. (2011) found that males averaged significantly larger than females for some measurements,

Table 5: Two external measurements for Molossus molossus caught at two localities: Ravine of Fonds Manoël in December 2009 and 2013 (locality 23 on Figure 1) and Ravine of Trou Manuel in December 2009 (locality 24 on Figure 1).

\begin{tabular}{lll}
\hline & Forearm & Weight \\
\hline Fonds Manoël: $f$ & $39.2 \pm 0.7(37.8-40.4) \mathrm{n}=13$ & $12.6 \pm 0.7(11.5-14.0) \mathrm{n}=12$ \\
Fonds Manoël: $\mathrm{m}$ & $40.3 \pm 0.7(39.1-42.0) \mathrm{n}=14$ & $14.3 \pm 1.5(11.5-17.0) \mathrm{n}=14$ \\
& $\mathrm{p}=0.0013$ & $\mathrm{p}=0.0026$ \\
Trou Manuel: $\mathrm{f}$ & $39.3 \pm 0.9(37.7-41.2) \mathrm{n}=25$ & $12.5 \pm 0.9(10.5-14.0) \mathrm{n}=25$ \\
Trou Manuel: $\mathrm{m}$ & $39.9 \pm 0.7(38.6-41.7) \mathrm{n}=21$ & $14.2 \pm 1.3(11.5-16.5) \mathrm{n}=10$ \\
& $\mathrm{p}=0.0236$ & $\mathrm{p}<0.0001$ \\
\hline
\end{tabular}

Values are presented as mean \pm standard deviation (range: minimum-maximum). f, females; $m$, males; $n$, sample size. $p$-Values for MannWhitney tests investigating sexual dimorphism. 
Table 6: Two external measurements for Monophyllus plethodon caught in three localities: Morne Tranchette in December 2013 (locality 14 on Figure 1); Route forestière de Caplet in March 2010 (location 11 on Figure 1); and Plateau Boucher (various dates; number 19 on Figure 1).

\begin{tabular}{lll}
\hline & Forearm & Weight \\
\hline Tranchette: $\mathrm{f}$ & $41.3 \pm 0.8(39.5-42.4) \mathrm{n}=10$ & $15.4 \pm 1.7(12.5-18.5) \mathrm{n}=10$ \\
Tranchette: $\mathrm{m}$ & $42.4 \pm 0.9(39.9-44.4) \mathrm{n}=56$ & $15.8 \pm 1.1(13.0-18.5) \mathrm{n}=54$ \\
& $\mathrm{p}=0.0008$ & $\mathrm{p}=0.3087$ \\
Caplet: $\mathrm{f}$ & $41.5 \pm 1.1(38.7-43.6) \mathrm{n}=13$ & $14.7 \pm 1.9(10.5-16.5) \mathrm{n}=9$ \\
Caplet: $\mathrm{m}$ & $42.3 \pm 1.1(39.9-44.7) \mathrm{n}=22$ & $14.8 \pm 0.8(13.5-16.0) \mathrm{n}=6$ \\
& $\mathrm{p}=0.0326$ & $\mathrm{p}=0.6756$ \\
Boucher: $\mathrm{f}$ & $41.3 \pm 1.2(39.0-43.5) \mathrm{n}=14$ & $15.2 \pm 1.1(13.5-17.0) \mathrm{n}=10$ \\
Boucher: $\mathrm{m}$ & $42.0 \pm 1.0(38.7-44.0) \mathrm{n}=80$ & $16.3 \pm 1.0(13.5-19.0) \mathrm{n}=77$ \\
& $\mathrm{p}=0.0126$ & $\mathrm{p}=0.0045$ \\
\hline
\end{tabular}

Values are presented as mean \pm standard deviation (range: minimum-maximum); f, females; $m$, males; $n$, sample size. $p$-Values for MannWhitney tests investigating sexual dimorphism.

such as the forearm and the length of the skull. Similarly, on Dominica, Hixon et al. (2012) found that males had a larger forearm than females.

Most Monophyllus were caught during the dry season (86\% of captures between January and June: $\chi^{2}=76.84$; $\mathrm{p}<0.0001)$. Reproduction seems limited to the dry season, with pregnant females being found in February $(n=3)$, March $(n=25)$ and April $(n=5)$. On Barbados, Genoways et al. (2011) found 13 lactating out of 14 females caught on 13 May 1975. On Dominica, Genoways et al. (2001) recorded eight pregnant females (out of nine captures) in March and April.

Monophyllus plethodon is clearly a species of elevation (Figure 2), with $62 \%$ of captures encountered above $600 \mathrm{~m}\left(\chi^{2}=184.72 ; \mathrm{p}<0.0001\right)$. At Plateau Boucher (altitude $665 \mathrm{~m})$ and Morne Tranchette $(740 \mathrm{~m})$, this species represents $59 \%$ and $93 \%$ of the captures, respectively (total samples for these two localities are 159 and 71 bats, respectively). Genoways et al. (2011) had already noticed that M. plethodon was "more abundant at higher elevations" on Barbados, but elsewhere the Antillean longtongued bat can also live in lower elevation xerophilous environments, such as Marie-Galante (Guadeloupe) where that species was found in several layers (aged 37,000 to 4000 years before present) of a late Pleistocene fossil deposit (Stoetzel et al. 2016).

\section{Myotis martiniquensis (Martinican Myotis)}

We captured 218 of these small insectivorous bats, 8.3\% of the whole database. The sex ratio was dominated by females: 134 females and 84 males $\left(\chi^{2}=11.47 ; p=0.0032\right)$. This warrants further investigation as to the social organization of this animal (harem structure), or the probability of a nearby colony of breeding females.

No clear sexual size dimorphism was found in two samples (Table 7): Forêt de Montravail (27 females and 15 males; MW $p=0.0155$ and 0.5821, for forearm and weight, respectively); Walking track between GrandRivière and Le Prêcheur (41 females and 28 males; MW $\mathrm{p}=0.301$ and 0.0363). On Barbados, Genoways et al. (2011) found no secondary sexual variation in Myotis nyctor, a species very similar in size and form to Myotis martiniquensis and which was considered conspecific until the molecular study by Larsen et al. (2012).

Table 7: Two external measurements for Myotis martiniquensis caught in two localities: Forêt de Montravail in February and December (locality 12 on Figure 1) and Sentier de Grand-Rivière au Prêcheur in December 2013 (locality 26 on Figure 1).

\begin{tabular}{lll}
\hline & Forearm & Weight \\
\hline Montravail: $f$ & $38.6 \pm 0.7(36.8-39.5) \mathrm{n}=27$ & $5.2 \pm 0.4(4.5-6.0) \mathrm{n}=16$ \\
Montravail: $\mathrm{m}$ & $38.1 \pm 0.6(37.2-39.2) \mathrm{n}=15$ & $5.4 \pm 0.7(4.5-7.0) \mathrm{n}=12$ \\
& $\mathrm{p}=0.0155$ & $\mathrm{p}=0.5821$ \\
Sentier: $\mathrm{f}$ & $37.6 \pm 0.9(35.1-39.1) \mathrm{n}=41$ & $5.3 \pm 0.4(4.5-6.0) \mathrm{n}=34$ \\
Sentier: $\mathrm{m}$ & $37.5 \pm 0.8(35.9-39.3) \mathrm{n}=28$ & $5.1 \pm 0.3(4.5-6.0) \mathrm{n}=26$ \\
& $\mathrm{p}=0.3012$ & $\mathrm{p}=0.0363$ \\
\hline
\end{tabular}

Values are presented as mean \pm standard deviation (range: minimum-maximum). $f$, females; $m$, males; $n$, sample size. $p$-Values for MannWhitney tests investigating sexual dimorphism. 
Adult females were caught in similar numbers during the dry $(\mathrm{n}=64)$ and the wet $(\mathrm{n}=70)$ seasons, and our sample does not contain any lactating or pregnant female. On Dominica where the distinct - but morphologically similar - species Myotis dominicensis was collected by Genoways et al. (2001), pregnant females (17 out of 24 captures) were observed in early April whereas lactating females (12 out of 15 captures) were observed by late July.

Myotis was found in 13 among the 24 capture-rich localities, for a total of 192 individuals (or 10.3\% of that sub-sample). There is no obvious elevational stratification of Myotis captures, but the majority (61\%) were netted between 151 and $300 \mathrm{~m}\left(\chi^{2}=75.93 ; \mathrm{p}<0.0001\right)$, and only eight of this species were netted above $300 \mathrm{~m}$. From our experience, Myotis appears related to the forests, especially the seasonal evergreen forest and the high altitude rainforests.

\section{Pteronotus davyi (Davy's naked-backed bat)}

Pteronotus davyi is not a common species in our data set, with 44 captures only (1.7\% of all 2613 bats). There is a strong bias in favor of females (35 versus 9; $\chi^{2}=15.36$; $\mathrm{p}=0.00046)$. The whole sample exhibits some sexual dimorphism in size, with females larger than males (MW $\mathrm{p}=0.0047$ and 0.0351 for forearm and weight, respectively: see Table 8).

Table 8: Two external measurements for Pteronotus davyi caught in various localities in Martinique.

\begin{tabular}{lll}
\hline & Forearm & Weight \\
\hline Females & $46.6 \pm 1.1(42.7-48.2) \mathrm{n}=35$ & $9.0 \pm 0.8(7.5-11.0) \mathrm{n}=33$ \\
Males & $45.6 \pm 0.9(44.3-47.1) \mathrm{n}=9$ & $8.3 \pm 0.7(7.5-9.5) \mathrm{n}=8$ \\
& $\mathrm{p}=0.0047$ & $\mathrm{p}=0.0352$ \\
\hline
\end{tabular}

Values are presented as mean \pm standard-deviation (range: minimum-maximum). $f$, females; $m$, males; $n$, sample size. $p$-Values for Mann-Whitney tests investigating sexual dimorphism.
Our sample did not include pregnant or lactating females. On Dominica, Genoways et al. (2001) recorded three pregnant females in March and one lactating animal in July. Pteronotus seems to be more frequently caught during the wet season ( $66 \%$ of captures occurred between July and December).

Only nine Pteronotus were caught in the 24 capturerich localities, thus representing less than $1 \%$ of the 1859 bats of that sub-sample. Our field observations were that Davy's naked-backed bats forage well above our nets (as also for Tadarida brasiliensis and Molossus molossus), and consequently understory low-level mist nets are not adequate for sampling this species.

\section{Sturnira angeli (yellow-shouldered bat)}

The small frugivorous Sturnira angeli ranks second in abundance (498 captures) in the whole data set (19\% of 2613 bats). We netted more females than males (304 versus $\left.194 ; \chi^{2}=12.30 ; p=0.00045\right)$.

Comparisons of forearm lengths and weights (Table 9) indicate that males are larger than females, as illustrated by samples from Beauséjour (36 females versus 32 males; MW $p=0.0004$ and 0.0060 for forearm and weight, respectively) or Grand Rivière (26 females and 17 males; MW $\mathrm{p}=0.0089$ and 0.0185 ). This is in contrast to what Genoways et al. (2001) found on Dominica where the forearm of females was slightly larger than that of males.

Sturnira angeli has been caught equally during the wet $(n=217)$ and the dry $(n=281)$ seasons $\left(\chi^{2}=1.312\right.$; $\mathrm{p}=0.2519$ ). Pregnant Sturnira have only been recorded in March ( $\mathrm{n}=23)$ and April $(\mathrm{n}=6)$, suggesting a single period of reproduction during the dry season. On Dominica, Genoways et al. (2001) reported pregnant females in late March ( $(n=8)$, mid-April $(n=3)$, June $(n=3)$ and July $(n=1)$.

Sturnira angeli was netted at 22 among the 24 capturerich localities, for a total of 376 individuals or $20.2 \%$ of

Table 9: Two external measurements for Sturnira angeli caught in two localities: Beauséjour in March 2007 and 2014 (locality 2 on Figure 1) and Sentier de Grand-Rivière au Prêcheur in December 2012 (locality 26 on Figure 1).

\begin{tabular}{lll}
\hline & Forearm & Weight \\
\hline Beauséjour: $\mathrm{f}$ & $43.1 \pm 1.0(40.5-45.5) \mathrm{n}=36$ & $20.5 \pm 2.2(17.5-24.5) \mathrm{n}=14$ \\
Beauséjour: $\mathrm{m}$ & $43.9 \pm 0.8(42.0-45.0) \mathrm{n}=32$ & $22.4 \pm 1.1(20.5-24.5) \mathrm{n}=19$ \\
& $\mathrm{p}=0.0004$ & $\mathrm{p}=0.0060$ \\
Sentier: $\mathrm{f}$ & $43.9 \pm 0.7(41.7-45.1) \mathrm{n}=26$ & $21.4 \pm 1.3(18.0-24.0) \mathrm{n}=17$ \\
Sentier: $\mathrm{m}$ & $44.4 \pm 0.6(42.9-45.4) \mathrm{n}=17$ & $22.7 \pm 1.7(20.0-26.0) \mathrm{n}=15$ \\
& $\mathrm{p}=0.0089$ & $\mathrm{p}=0.0185$ \\
\hline
\end{tabular}

Values are presented as mean \pm standard-deviation (range: minimum and maximum). $f$, females; $m$, males; $n$, sample size. $p$-Values for Mann-Whitney tests investigating sexual dimorphism. 
this sub-sample. Sturnira angeli is found throughout the island, from sea level up to $740 \mathrm{~m}$ (locality of Morne Tranchette), in numbers slightly different from those expected by chance for the various altitudinal levels $\left(\chi^{2}=24.38\right.$; $\mathrm{p}<0.0001)$. There were less yellow-shouldered bats caught in two elevational zones (0-150 m; 601-750 m) than expected; and there were more $S$. angeli in two other zones (151-300 m; 301-450 m) than expected if that taxon was equally foraging in all elevational zones - this might be related to fruit availability and altitude, but we have not investigated further.

\section{Tadarida brasiliensis (Brazilian free-tailed bat)}

Tadarida is the least frequently caught molossid, with only 23 individuals (or $0.9 \%$ out of 2613 bats).

The sex ratio seems equal (11 females and 12 males) but our sample is too small for conclusive evidence. Mist net captures of S. Pedersen (in littera, 18 February 2010) on Montserrat included more females $(\mathrm{n}=23)$ than males $(\mathrm{n}=8)$. The whole Martinique sample indicates no sexual size dimorphism (Table 10) in the forearm length or in the weight (MW $p=0.5740$ and 0.7393 , respectively). One pregnant female was observed in May. On Dominica, Genoways et al. (2001) reported reproductive females in July (11 lactating and four pregnant out of 18 captures) and early September (five lactating out of six). Most (20 out of 23) of the Tadarida were caught in the 24 capture-rich localities. Tadarida was found from sea level up to $380 \mathrm{~m}$ (locality $9=$ Domaine d'Estripault). Clearly, the low number of captures is related to the ecology of the species, which forages high above the trees.

\section{Discussion}

Robust inventories for depicting the community of bats on an island are hampered by the inadequacy of ground-based

Table 10: Two external measurements for Tadarida brasiliensis caught in various localities in Martinique.

\begin{tabular}{lll}
\hline & Forearm & Weight \\
\hline Females & $37.4 \pm 0.8(36.5-38.5) \mathrm{n}=11$ & $8.4 \pm 0.8(7.5-9.7) \mathrm{n}=10$ \\
Males & $37.2 \pm 0.9(36.0-39.1) \mathrm{n}=12$ & $8.3 \pm 0.5(7.5-9.0) \mathrm{n}=11$ \\
& $\mathrm{p}=0.5740$ & $\mathrm{p}=0.7393$ \\
\hline
\end{tabular}

Values are presented as mean \pm standard deviation (range: minimum-maximum). $f$, females; $m$, males; $n$, sample size. $p$-Values for Mann-Whitney tests investigating sexual dimorphism. netting strategies, something which is painfully obvious to field biologists (Simmons and Voss 1998, Larsen et al. 2007). Species may simply be able to avoid mist nets (echolocating and slow-flying small insectivorous and nectarivorous bats such as Myotis and/or Monophyllus), or fly where we cannot place mist nets (above large areas of water: Noctilio; much higher than our ground-based mist nets: high flying insectivorous molossids), or are quite simply rare (Natalus, perhaps).

Consequently, we acknowledge that mist net capture bias significantly reduces the accuracy of faunal inventory work and may underestimate species diversity on Martinique. Such a severe bias related to mist net captures was reported by Larsen et al. (2007) on Montserrat island. We have assumed that all Artibeus that we caught were the species Artibeus jamaicensis, and that the sibling species Artibeus schwartzi (see Larsen et al. 2010) is not present in Martinique. Based on the measurement of the breadth across the outer edges of the second upper molars, a sample of 62 Artibeus that were measured in 2013-2015 had a mean value of $12.69 \mathrm{~mm}$ (standard deviation $0.34 \mathrm{~mm}$, range $11.9-13.3 \mathrm{~mm}$ ). These values are much more in line (see Table S3 in Larsen et al. 2010) with the reference material attributed by Larsen et al. (2010) to $A$. jamaicensis (mean of $12.6 \mathrm{~mm}$, range 12.0-13.2) than to $A$. schwartzi (mean of $14.0 \mathrm{~mm}$, range 13.2-14.9).

Caution must also be taken when interpreting differences in adult sex ratios, because it has been shown - in some bird species - that mist net captures might lead to biased estimates (Amrhein et al. 2012), in relation to behavioral differences related to territory marking and/ or defense. In the same vein, another caveat is the long period of data acquisition (12 years, from 2004 to 2015), and it might be that some populations have changed sex ratios, but an inspection of our raw data is inconclusive (data not shown).

Nevertheless, Table 11 indicates that there is a strong female-biased sex ratios in Molossus molossus and Pteronotus davyi, and the reverse is true for Ardops nichollsi and Monophyllus plethodon where males are much more numerous. Other taxa with a non-equilibrated sex ratio are Brachyphylla cavernarum, Myotis martiniquensis and Sturnira angeli. Finally, the sex ratio seems at equilibrium in the samples of Artibeus jamaicensis and Tadarida brasiliensis. Caution is needed because sex ratios might also differ between different geographic samples for the same taxon, as indicated by our results when comparing Montserrat (S. Pedersen, in littera, 18 February 2010) with Martinique. In A. jamaicensis, males are as abundant as females in Martinique whereas females are netted more often in Montserrat. In B. cavernarum, the sex ratio is 
Table 11: Summary statistics for the nine species caught in the 24 capture-rich localities (i.e. with at least 30 individuals per locality).

\begin{tabular}{|c|c|c|c|c|}
\hline Species & Sex ratio (female:male) & Sexual dimorphism & Occurrence (a) & Abundance (b) \\
\hline Ardops nichollsi & $1.0: 4.1$ & $f>m$ & 15 & 4.4 \\
\hline Artibeus jamaicensis & $1.0: 1.1$ & $f \sim m$ & 22 & 32.9 \\
\hline Brachyphylla cavernarum & $1.0: 1.3$ & $f \sim m$ & 13 & 9.4 \\
\hline Molossus molossus & $1.0: 0.4$ & $\mathrm{f}<\mathrm{m}$ & 11 & 7.3 \\
\hline Monophyllus plethodon & $1.0: 3.1$ & $\mathrm{f}<\mathrm{m}$ & 12 & 13.9 \\
\hline Myotis martiniquensis & $1.0: 0.6$ & $f \sim m$ & 13 & 10.3 \\
\hline Pteronotus davyi & $1.0: 0.3$ & $f>m$ & 5 & 0.5 \\
\hline Sturnira angeli & $1.0: 0.6$ & $\mathrm{f}<\mathrm{m}$ & 22 & 20.2 \\
\hline Tadarida brasiliensis & 1.0:1.1 & $f \sim m$ & 5 & 1.1 \\
\hline
\end{tabular}

Sexual dimorphism for weight and forearm length values. The two roost-localities are not included here. (a) Occurrence is the number of localities where found; (b) abundance is the percentage of individuals caught out of the total sample of 1859 bats.

reversed: more males on Martinique, more females on Montserrat. It is premature to invoke sampling bias which could be responsible for differences between neighbor islands within and among the Lesser Antilles because these are insular populations, which may have experienced different recent populational histories in relation to hurricanes, volcanic activity, local droughts and food availability (Wong et al. 2005, Pedersen et al. 2009). Also, Lesser Antillean islands differ from each other by the extent of modern monoculture (sugar cane and banana trees, mainly) which has resulted in forest fragmentation and eventually disappearance. Disturbances to bat communities are mainly due to hurricanes, whose frequency, intensity and return time can vary from island to island, and are particularly severe in the Lesser Antilles, as demonstrated by Willig et al. (2010).

With regard to sexual size dimorphism (see Table 11), adult (excluding pregnant animals) females are larger and heavier than males in Ardops and Pteronotus. By contrast, males are heavier and larger in Molossus (a well-known observation: Freeman 1981, Willig and Hollander 1995) and Sturnira. Finally, there seems to be no gross external sexual dimorphism in Artibeus, Brachyphylla, Myotis and Tadarida. We could not find any evident relationship with taxonomy, body size, feeding guild, relative weight of newborn or any other life history trait. Since the study by Swanepoel and Genoways (1978) on the morphological variation in Antillean samples of Brachyphylla spp., numerous examples have suggested that there is geographic variation from island to island for sexual dimorphism. Hence, males of Brachyphylla cavernarum are larger in some Martinique populations and in Saint-Martin/Sint Maarten, whereas they are smaller than females in Barbados (Genoways et al. 2007, 2011). A similar case is for Molossus molossus, in which females are smaller than males in Martinique (this paper) but larger on other islands such as Guadeloupe and Barbados (Genoways et al. 1981, 2011). Even in continuous landmasses, such as peninsular India, sexual dimorphism can vary across a latitudinal gradient, as reported for the Indian fruit bat Cynopterus sphinx by Storz et al. (2001).

Another note of caution is that our data set was very heterogeneous within the calendar year. About $94 \%$ of all 2613 captures have been made in just 4 months: February and March (1189 bats) and November and December (1257 bats). At most, we can contrast the dry season (January to June) and wet season (July to December).

Reproductive (pregnancy, lactation) females have been found almost exclusively during the dry season for Artibeus jamaicensis (86 out of 87 females), for Monophyllus plethodon (all 33 reproductive females) and for Sturnira angeli (all 29 reproductive females). Data are too few for the other species.

When considering the 24 capture-rich localities (Table 11), there is a positive relationship between occurrence (number of localities where a species has been caught) and abundance (number of individuals caught for a species): Pearson's $\mathrm{R}=0.865, \mathrm{p}=0.0026$; Kendall's tau $=0.609, p=0.0222$. There is no relationship (Pearson's $\mathrm{R}=0.351$ ) between the number of species (from 2 to 8 ) and the number of captures (from 30 to 261). The three localities in orchards (numbered 10, 16 and 17 in Figure 1) yielded 212 individuals of five species whereas the 21 localities in natural forests yielded 1647 bats of nine species, thus the relative abundance of bats caught per locality does not differ between the two independent surveys (forests versus orchards) combined in this study. Similarly, there is no relation (Pearson's $R=0.255$ ) between the number of species in any locality and the elevation of a particular netting locality (from sea level to $740 \mathrm{~m}$ ). Some species of bats seem more or less abundant according to elevation, as the large frugivorous Artibeus jamaicensis are much 
more abundant at lower elevations whereas the reverse is observed for the nectarivorous Monophyllus plethodon. By contrast, a smaller frugivorous taxon - Ardops nichollsi - appears more common at higher elevations, an observation shared by Scott Pedersen (personal communication 18 February 2010) for some other Lesser Antillean islands. These preliminary data need to be tested through further examination of food availability with elevation for these frugivorous-nectarivorous bats.

The 24 capture-rich localities had an average of five different species (standard deviation of 1.84). The highest occurrence (frequency of presence among the 24 capturerich localities) is observed in Artibeus and Sturnira (22 localities) whereas the least frequently found species are Pteronotus and Tadarida (five localities only, but we caution that those taxa forage well above our mist nets). The occurrence of five other taxa ranged from 11 (Molossus) to 15 (Ardops) localities. With similar techniques as ours (mist nets at ground level), Genoways et al. (2011) caught 933 specimens of bats on Barbados with decreasing abundance of $71 \%$ Artibeus jamaicensis, $12 \%$ Molossus molossus, $11 \%$ Brachyphylla cavernarum and the remaining 6\% being Monophyllus plethodon, Myotis nyctor and Noctilio leporinus. By comparison, the bat community of Martinique seems more balanced because the four commonest taxa accounted for $77 \%$ of the global sample with the most abundant species being "only" 33\% (A. jamaicensis). The next three common taxa are Sturnira (20\%), Monophyllus (14\%) and Myotis (10\%) with the remaining five species comprising slightly less than $23 \%$.

Whereas this study brings new data regarding relative abundance, sex ratio, sexual size dimorphism and timing of reproduction for nine species of Martinique bats, it opens new questions which can only be addressed by

Appendix 1: List of bats collected and preserved as vouchers in the scientific collections of Museum National d'Histoire Naturelle de Paris (MNHN).

\begin{tabular}{|c|c|c|c|c|}
\hline Museum number & Species & Sex & Locality in Martinique & Date \\
\hline $2005-888$ & Ardops nichollsi & $\mathrm{m}$ & Fonds Saint-Denis: Plateau Boucher & 26-Apr.-05 \\
\hline $2005-889$ & Ardops nichollsi & $\mathrm{m}$ & Fonds Saint-Denis: Plateau Boucher & 27-Apr.-05 \\
\hline 2013-005 & Ardops nichollsi & $\mathrm{m}$ & Le Carbet: Bout-Bois & 09-Dec.-11 \\
\hline $2005-887$ & Ardops nichollsi & $\mathrm{m}$ & Morne Rouge: Domaine d'Estripault & 23-Apr.-05 \\
\hline 2013-002 & Artibeus jamaicensis & $f$ & Grand-Rivière: Habitation Beauséjour & 07-Dec.-11 \\
\hline 2013-1937 & Artibeus jamaicensis & $\mathrm{m}$ & Grand-Rivière: Habitation Beauséjour & 21-Mar.-13 \\
\hline 2013-1938 & Artibeus jamaicensis & $\mathrm{m}$ & Grand-Rivière: Habitation Beauséjour & 21-Mar.-13 \\
\hline $2005-890$ & Artibeus jamaicensis & $\mathrm{m}$ & Le Prêcheur: Case Petit & 20-Apr.-05 \\
\hline $2005-787$ & Artibeus jamaicensis & $\mathrm{m}$ & Le Prêcheur: Habitation Céron & 19-Apr.-05 \\
\hline 2013-001 & Brachyphylla cavernarum & $\mathrm{m}$ & Saint-Esprit: Peter Maillet (orchards) & 16-Nov.-11 \\
\hline 2008-971 & Brachyphylla cavernarum & $f$ & Trois-Ilets: village Poterie & 04-Feb.-08 \\
\hline $2008-972$ & Brachyphylla cavernarum & $f$ & Trois-Ilets: village Poterie & 04-Feb.-08 \\
\hline $2008-973$ & Brachyphylla cavernarum & $f$ & Trois-Ilets: village Poterie & 04-Feb.-08 \\
\hline $2005-791$ & Molossus molossus & $\mathrm{m}$ & Le Prêcheur: Habitation Céron & 19-Apr.-05 \\
\hline $2005-792$ & Molossus molossus & $\mathrm{m}$ & Le Prêcheur: Habitation Céron & 19-Apr.-05 \\
\hline $2005-793$ & Molossus molossus & $f$ & Le Prêcheur: Habitation Céron & 19-Apr.-05 \\
\hline $2005-794$ & Molossus molossus & $f$ & Le Prêcheur: Habitation Céron & 19-Apr.-05 \\
\hline $2005-891$ & Monophyllus plethodon & $\mathrm{m}$ & Fonds Saint-Denis: Plateau Boucher & 26-Apr.-05 \\
\hline $2005-892$ & Monophyllus plethodon & $\mathrm{m}$ & Fonds Saint-Denis: Plateau Boucher & 26-Apr.-05 \\
\hline $2005-893$ & Monophyllus plethodon & $f$ & Fonds Saint-Denis: Plateau Boucher & 26-Apr.-05 \\
\hline $2005-894$ & Monophyllus plethodon & $\mathrm{m}$ & Fonds Saint-Denis: Plateau Boucher & 27-Apr.-05 \\
\hline $2008-974$ & Myotis martiniquensis & $\mathrm{m}$ & Grand-Rivière: Habitation Beauséjour & 18-Feb.-08 \\
\hline $2005-896$ & Myotis martiniquensis & $f$ & Morne Rouge: Domaine d’Estripault & 25-Apr.-05 \\
\hline $2005-895$ & Myotis martiniquensis & $f$ & Morne Rouge: Domaine d'Estripault & 23-Apr.-05 \\
\hline 2008-1495 & Pteronotus davyi & $f$ & Saint-Esprit: Peter Maillet (orchards) & 27-Feb.-09 \\
\hline 2013-003 & Sturnira angeli & $\mathrm{m}$ & Le Carbet: Bout-Bois & 09-Dec.-11 \\
\hline 2013-004 & Sturnira angeli & $\mathrm{m}$ & Le Carbet: Bout-Bois & 09-Dec.-11 \\
\hline 2013-006 & Sturnira angeli & $\mathrm{m}$ & Le Prêcheur: Habitation Céron & 24-Sep.-12 \\
\hline 2013-008 & Sturnira angeli & $f$ & Le Prêcheur: Habitation Céron & 24-Sep.-12 \\
\hline $2005-795$ & Sturnira angeli & $f$ & Le Prêcheur: Case Petit & 22-Apr.-05 \\
\hline 2013-007 & Tadarida brasiliensis & $\mathrm{m}$ & Le Prêcheur: Habitation Céron & 24-Sep.-12 \\
\hline
\end{tabular}

Collecting permit reference 061297, issued to the senior author by Prefecture de la Martinique on 11 April 2006. 
future field research. Research questions include where are the larger roosts and breeding colonies of bats in Martinique - and what is their composition in terms of sex ratio? What are the proximal causes of the different sex ratios found in some species, such as netting probabilities related to different mating systems, or different foraging areas? So much remains to be learned!

Acknowledgments: We would first like to deeply acknowledge our field mates in Martinique, including Michel Barataud, Remi Picard and Sylvie Giosa. A special thanks to Jean-Louis de Lucy, who year after year offered his friendly hospitality to the senior author at Habitation Beauséjour (municipality of Grand Rivière). Scott Pedersen generously shared some of his unpublished data from Montserrat, and suggested many changes for improving our manuscript - many thanks. Arnaud Lenoble also made constructive suggestions upon reading the first version of this manuscript; Burton Lim was so kind as to polish our poorly written English, but of course all the remaining mistakes are ours. Our research was funded through several contracts with the French government agency DEAL (Direction de l'Environnement, de l'Amenagement, et du Logement) of Martinique, and we deeply acknowledge Vincent Arenales, Cyrille Barnerias and Julien Mailles. Permits for capturing and handling bats (Chiroptera are protected by law in Martinique) were obtained from DEAL. G. Issartel and J. Jemin acknowledge the support of Agence Nationale de Sécurité Sanitaire de l'Alimentation, de l'Environnement et du Travail (ANSES, Maisons-Alfort, France) and of Societe Francaise pour l'Etude et la Protection des Mammifères (SFEPM, Bourges, France). J. Jemin is particularly indebted to Groupe Mammalogique et Herpétologique du Limousin (GMHL, Aixe-sur-Vienne, France) for their administrative help.

\section{References}

Albert, P. and J. Spieser. 1999. Atlas climatique: le temps à La Martinique. Pp. 1-104. Météo-France, Direction interrégionale Antilles-Guyane, Fort de France.

Amrhein, V., B. Scaar, M. Baumann, N. Mine, J.-P. Binnert and F. Korner-Nievergelt. 2012. Estimating adult sex ratios from bird mist netting data. Methods Ecol. Evol. 3: 713-720.

Baker, R.J. and H.H. Genoways. 1978. Zoogeography of Antillean bats. Pp. 53-97 in F. B. Gill, ed. Zoogeography in the Caribbean. Acad. Nat. Sci. Philadelphia, Philadelphia.

Baker, R. J., H. H. Genoways and J.C. Patton. 1978. Bats of Guadeloupe. Occas. Papers, The Museum of Texas Tech. University 50: 1-16.

Barataud, M., S. Giosa, G. Issartel, J. Jemin and J.-P. Fiard. 2015. Bioévaluation des forêts de Martinique par l'étude de l'activité des chiroptères - Résultats des captures - complément du rap- port de synthèse 2014. Pp. 1-30. Technical report for SFEPM/ DEAL Martinique/FEDER/ONF, Fort de France.

Bradbury, J.W. and S.L. Vehrencamp. 1976. Social organization and foraging in Emballonuridae bats. I - Field Studies. Behav. Ecol. Sociobiol. 1: 337-381.

Daly, M. and M. Wilson. 1978. Sex, evolution, and behavior. Wadsworth Publishing Company., Belmont (California).

Emlen, S.T. and L. W. Oring. 1977. Ecology, sexual selection, and the evolution of mating systems. Science 197: 215-223.

FAO. 2010. Evaluation des ressources forestières mondiales 2010 - rapport national: Martinique. pp. 1-54. Technical report FAO, Roma (Italy).

Freeman, P.W. 1981. A multivariate study of the family Molossidae (Mammalia, Chiroptera): morphology, ecology, evolution. Fieldiana Zoology 7: 1-173.

Gager, Y., O. Gimenez, T.M. O’Mara and D.K.N. Dechmann. 2016. Group size, survival and surprisingly short lifespan in socially foraging bats. BMC Ecol. 16: 1-12.

Gardner, A.L., C.O. Handley and D.E. Wilson. 1991. Survival and relative abundance. In: (C.O. Handley, D.E. Wilson and A.L. Gardner, eds.) Demography and natural history of the common fruit bat, Artibeus jamaicensis, on Barro Colorado Island, Panama. Smithsonian Institution Press, Washington, D.C. pp. 53-76.

Genoways, H.H., R.C. Dowler and C.H. Carter. 1981. Intraisland and interisland variation in Antillean populations of Molossus molossus (Mammalia: Molossidae). Ann. Carnegie Mus. 50: 475-492.

Genoways, H.H., R.M. Timm, R.J. Baker, C.J. Phillips and D.A. Schlitter. 2001. Bats of the West Indian island of Dominica: natural history, areography, and trophic structure. Spec. Publ., Museum of Texas Tech University 43: 1-44.

Genoways, H.H., R.J. Baker, J.W. Bickham and C.J. Phillips. 2005. Bats of Jamaica. Spec. Publ. Museum Texas Tech University 48: 1-155.

Genoways, H.H., S.C. Pedersen, P.A. Larsen, G.G. Kwiecinski and J. Huebschman. 2007. Bats of Saint Martin, French West Indies/ Sint Maarten, Netherlands Antilles. Mastozool. Neotrop. 14: 169-188.

Genoways, H.H., R.J. Larsen, S.C. Pedersen, G.G. Kwiecinski and P.A. Larsen. 2011. Bats of Barbados. Chiropt. Neotrop. 17: 1029-1054.

Hammer, Ø., D.A.T. Harper and P.D. Ryan. 2011. PAST: paleontological statistics software package for education and data analysis. Palaeontol. Electr. 4: 1-9.

Hixon, S., A. Brooks, B. Miculka, C. Richmond, D. Warrendorf, A. Whitmire, B. Wilkins, T. Lacher and J.B. Woolley. 2012. Wing morphology, flights speeds and insights into niche structure in Caribbean bats from Dominica. Chiropt. Neotrop. 18: 1067-1073.

Jones, K.J. and H.H. Genoways. 1973. Ardops nichollsi. Mamm. Species 24: 1-2.

Joseph, P. 2016. The spatio-temporal interfaces within the lesser Antilles vegetation (the example of the Island of Martinique). Open Access Library Journal 3: 1-17. doi: 10.4236/oalib.1102463.

Larsen, R.J., K.A. Boegler, H.H. Genoways, W.P. Masefield, R.A. Kirsch and S.C. Pedersen. 2007. Mist-nets bias, species accumulation curves, and the rediscovery of two bats on Montserrat (Lesser Antilles). Acta Chiropte. 9: 423-435.

Larsen, P.A., M.R. Marchan-Rivadeneira and R.J. Baker. 2010. Natural hybridization generates mammalian lineage with species characteristics. Proc. Natl. Acad. Sci. USA 107: 11447-11452. 
Larsen, R.J., M.C. Knapp, H.H. Genoways, F.A.A. Khan, P.A. Larsen, D.E. Wilson and R.J. Baker. 2012. Genetic diversity of neotropical Myotis (Chiroptera: Vespertilionidae) with an emphasis on South American Species. PLoS One 7: e46578.

McCracken, G.F. and G.S. Wilkinson. 2000. Bat mating systems. Pp. 321-362 in E.G. Crichton and P.H. Krutzsch, eds. Reproductive biology of bats. Academic Press., London.

Myers, P. 1978. Sexual dimorphism in size of vespertilionid bats. Amer. Nat. 112: 701-711.

Pedersen, S.C., H.H. Genoways, M.N. Morton, V.J. Swier, P.A. Larsen, R.A. Adams and J.D. Appino. 2006. Bats of Antigua, northern Lesser Antilles. Occas. Papers Museum, Texas Tech University 249: 1-18.

Pedersen, S.C., P.A. Larsen, H.H. Genoways, M.N. Morton, K.C. Lindsay and J. Cindric. 2007. Bats of Barbuda, Northern Lesser Antilles. Occas. Papers Museum, Texas Tech University 271: 1-19.

Pedersen, S.C., G.G. Kwiecinski, P.A. Larsen, M.N. Morton, R.A. Adams, H.H. Genoways and V.J. Swier. 2009. Bats of Montserrat: population fluctuation in response to hurricanes and volcanoes, 1978-2005. In: (T.H. Fleming and P.A. Racey, eds.) Island Bats: Evolution, Ecology, and Conservation. University of Chicago Press, Chicago, IL. pp. 302-340.

Pedersen, S.C., H.H. Genoways, G.G. Kwiecinski, P.A. Larsen and R.J. Larsen. 2013. Biodiversity, biogeography, and conservation of bats in the Lesser Antilles. Biodiversité insulaire: la flore, la faune et l'homme dans les Petites Antilles, Fort de France, Martinique 62-73.

Picard, R. and F. Catzeflis. 2013. Première étude des chauves-souris dans les goyaveraies de Martinique. Actes du Colloque international: Biodiversité insulaire - la flore, la faune et l'homme - dans les Petites Antilles, Fort de France 174-183.

Racey, P. A. 2009. Reproductive assessment of bats. In: (T.H. Kunz and S. Parsons, eds.) Ecological and behavioral methods for the study of bats. Johns Hopkins University Press, Baltimore, USA. pp. 249-264.

Sikes, R.S. and W.L. Gannon. 2011. Guidelines of the American Society of Mammalogists for the use of wild mammals in research. J. Mamm. 92: 235-253.

Simmons, N.B. and R.S. Voss. 1998. The mammals of Paracou, French Guiana: a neotropical lowland rainforest fauna. Part 1. Bats. Bull. Amer. Mus. Nat. Hist. 237: 1-219.

Stoetzel, E., A. Royer, D. Cochard and A. Lenoble. 2016. Late quaternary changes in bat palaeobiodiversity and palaeobio- geography under climatic and anthropogenic pressure: new insights from Marie-Galante, Lesser Antilles. Quat. Sci. Rev. 143: 150-174.

Storz, J.F., J. Balasingh, H.R. Bhat, P.T. Nathan, A. Prakash, D.P. Swami Doss and T.H. Kunz. 2001. Clinal variation in body size and sexual dimorphism in an Indian fruit bat, Cynopterus sphinx (Chiroptera: Pteropodidae). Biol. J. Linn. Soc. 72: 17-31.

Swanepoel, P. and H.H. Genoways. 1978. Revision of the Antillean bats of the genus Brachyphylla (Mammalia: Phyllostomidae). Bull. Carnegie Museum Nat. Hist. 12: 1-53.

Teissier du Cros, R. and C. Vidal. 2006. Mapping Martinique's forests and other natural lands for land planning and development. In: (R.E. McRoberts, G.A. Reams, P.C. Van Deusen and W.H. McWilliams, eds.) Eighth annual forest inventory and analysis symposium 16-19 October 2006. U.S. Department of Agriculture, Forest Service, Monterey, CA. pp. 31-38.

Velazco, P.M. and B.D. Patterson. 2013. Diversification of the yellow-shouldered bats, genus Sturnira (Chiroptera, Phyllostomidae), in the New World tropics. Mol. Phylogen. Evol. 68: 683-698.

Williams, D.F. and J.S. Findley. 1979. Sexual size dimorphism in vespertilionid bats. Amer. Midland Nat. 102: 113-126.

Willig, M.R. and R.R. Hollander. 1995. Secondary sexual dimorphism and phylogenetic constraints in bats: a multivariate approach. J. Mamm. 76: 981-992.

Willig, M.R., S.J. Presley, C.P. Bloch and H.H. Genoways. 2010. Macroecology of Caribbean bats: effects of area, elevation, latitude, and hurricane-induced disturbance. In: (T.H. Fleming and P.A. Racey, eds.) Island bats: evolution, ecology, and conservation. University of Chicago Press, Chicago. pp. 216-264.

Wilson, D.E., C.O. Handley and A.L. Gardner. 1991. Reproduction on Barro Colorado Island. In: (C.O. Handley, D.E. Wilson and A.L. Gardner, eds.) Demography and natural history of the common fruit bat, Artibeus jamaicensis, on Barro Colorado Island, Panama. Smithsonian Institution Press, Washington, D.C. pp. 43-52.

Wong, P.P., E. Marone, P. Lana, M. Fortes, D. Moro, J. Agard, L. Vicente, J. Thonell, P. Deda and K.J. Mulongoy. 2005. Island systems. In: (R. Hassan, R. Scholes and N. Ash, eds.) Ecosystems and human well-being. Millennium Ecosystems Assessment, Washington, DC. pp. 663-680. 